Review Paper

\title{
LEGAL PROVISIONS ON VIOLENCE IN SPORTS AND DISPUTABLE ISSUES IN COURT PRACTICE
}

\author{
UDC 343.343.3:796.093
}

\author{
Jelena Tasić \\ Judicial Assistant, Basic Court in Niš
}

\begin{abstract}
The Act on the Prevention of Violence at Sports Events, which regulates the behaviour of participants in sports events, contains numerous novelties related to this form of criminal offences. Large sports events are frequently tarnished by serious violence, such as property damage and intentionally harmful physical assaults with occasional fatal consequences, which call for an adequate response from the state authorities responsible for this form of criminal behaviour. This paper discusses the most relevant legal provisions related to violence in sports, and analyzes certain disputable issues and the existing case law, with specific reference to particular problems arising in judicial practice.
\end{abstract}

Key words: sport, violence, legal regulations, practical issues

\section{INTRODUCTION}

Fair-play is presumed in sports. The rules of fair-play are supposed to be observed and practiced in sports events. However, for years, sport has been closely linked to violence, not only abroad but also on the territory of former SFRY, its former constituent republics and the Republic of Serbia.

Violence is visible in all sports, both team and individual ones, but football appears to be the sport in which it is most frequently demonstrated. Most of the European countries have been combating violence in sports for more than thirty years. The seriousness of this issue may be illustrated by the Heysel Stadium disaster in Brussels in 1985, which occurred just before the start of the 1985 European Cup Final between the football clubs Juventus from Turin and Liverpool from Liverpool, when 39 people, mostly Italians and Juventus fans, were killed in the riot leading to the stadium wall collapse. In the aftermath of this tragedy, the international community responded to this violence previously unrecorded at sports events by adopting the 1985 European Convention on Spectator Violence and Misbehaviour at Sports Events and in particular at Football Matches.

Received December $12^{\text {th }}, 2018 /$ Accepted December $21^{\text {st }}, 2018$

Corresponding author Jelena Tasić, LL.B., Judicial Assistant, Basic Court in Niš, Republic of Serbia,

E-mail: jelena.tasic@ni.os.sud.rs 
Various instances of violence at sports events were also recorded in the former SFRY. One particular incident of sports violence has remained in the collective memory as a symbolic forewarning of the impending dissolution of the SFRY. Namely, in the Yugoslav Cup Final, the football match between FC Dinamo from Zagreb and FC Red Star from Belgrade was not played due to the mayhem caused by a number of fights between Dinamo and Red Star fans which started in the streets prior to the match but later continued at the Maksimir Stadium (Zagreb) and in the playground, resulting in mutual clashes between the players and direct confrontation with the law enforcement authorities. ${ }^{1}$

Sports violence has become a global phenomenon, which may be illustrated by numerous incidents at sporting events in other European countries. In a recent incident in Greece, for example, a football match between FC Paok Salonika and AEK Athens was interrupted by the- Paok owner who stormed onto the pitch armed with a gun after the referee disallowed his team a goal; as a result, the Greek Superleague was suspended by the Greek government. ${ }^{2}$. Following violent behaviour of disappointed fans of the British football club West Ham United, the club management decided to ban a certain number of its fans from the stadium for life. ${ }^{3}$

\section{INTERNATIONAL AND NATIONAL REGULATIONS:}

\section{Legal Documents on Sports Violence}

The Heysel Stadium disaster led to the adoption of the European Convention on Spectator Violence and Misbehaviour at Sports Events and in particular at Football Matches, adopted by the Council of Europe, as the oldest European political organization, on 19 August $1985 .{ }^{4}$ Article 1 of this document states that the Convention is aimed at "preventing and controlling violence and misbehaviour by spectators at football matches", by coordinating the policies and actions of government departments and other public agencies (Article 2), ensuring the implementation of relevant measures to prevent misconduct (Article 3), and promoting international cooperation between national sports authorities (Article 4). The Convention was ratified by the Republic of Serbia on 28 February 2001, and it came into force on 1 April 2001. The Convention was ratified by 40 European states (Stepanović, 2011: 81).

This international document is closely related to some other documents regulating behaviour in various sports, especially in football. Of particular significance are the regulations adopted Fédération Internationale de Football Association (FIFA), and the Union of the European Football Associations (UEFA). The statutes and particularly the disciplinary regulations of these football associations determine preventive and repressive

1 Vreme, Slučaj "Maksimir" - dvadeset godina posle, by Zoran Majdin, br. 1011, 20 maj 2010; available at http://www.vreme.co.rs/cms/view.php?id=931952, accessed on 20 March 2018.

2 The Guardian, Greek Superleague suspended after team owner invades pitch with a gun, by Helena Smith,12 March 2018; available at https://www.theguardian.com/football/2018/mar/12/greek-football-match-stoppedafter-team-owner-invades-pitch-with-a-gun, accessed on 20 March 2018.

${ }^{3}$ The Guardian, West Ham promise to ban fans for life after Upton Park violence, by A. Smith, D. Hytner, 11 May 2016, available at https://www.theguardian.com/football/2016/may/11/west-ham-ban-fans-for-life-uptonpark-violence-manchester-united, accessed on 20 March 2018.

${ }^{4}$ CETS 120 European Convention on Spectator Violence and Misbehaviour at Sports Events and in particular at Football Matches, Strasbourg, 19.VIII.1985; available at https://rm.coe.int/168007a086 
measures to be taken. They include fines to be paid by football clubs and football associations, playing of a match behind closed doors or in a third country, suspension of a football stadium and exclusion from international competitions organized by the aforementioned federations. The world and European football union have been combating racism in football and other forms of discrimination in sports (Dimovski, Ilić, 2015: 122).

The 1985 European Convention on Violence at Sports Events represents the basis of criminal legislation in sports (penal and misdemeanour law) for all the states that ratified it. Moreover, the ratification presupposed the passing and enforcement of national laws. Whereas the Convention lists neither the criminal offences which are to be regulated by national laws nor the elements constituting the character of these criminal offences, it indisputably demands from the countries that ratified it to enact and enforce their own functional mechanisms of legal protection against violence at sports events (Jašarević, Samouk-Jašarević, 2016: 653).

In compliance with the obligation assumed under the 1985 Convention, the Republic of Serbia adopted a special legislative act on the protection of sport and sports events, the Act on the Prevention of Violence and Misconduct at Sports Events (hereinafter: the PVMSE Act) of $2003,{ }^{5}$ which contains articles on specific criminal offences and criminal law protection. The PVMSE Act prescribes diverse measures aimed at preventing violence and misconduct at sports events and gatherings, as well as penalty measures for the criminal act of violent behaviour at sports events and numerous provisions related to the criminal offences committed by certain public officials or authorized persons.

At the time when this Act still included the criminal offence of violent behaviour at sports events as a special criminal act, the Government of the Republic of Serbia adopted the National Youth Strategy (2008) ${ }^{6}$. Among other things, this document stated that the data provided by the Ministry of Internal Affairs of the Republic of Serbia showed a constant increase in the violent spectator incidents at sports events on the territory of the Republic of Serbia. According to these data, 159 cases of serious violation of public peace and order at sports events were reported in 2006, in which 13 individuals were seriously injured and 156 persons sustained minor injuries. During the first ten months of the year 2007, there were 87 cases of serious violation of public peace and order, in which 23 persons sustained serious injuries and 172 individuals had minor injuries. Although it might not have been a crucial factor, the legislator responded by introducing changes in the criminal law provisions on to this matter, which were subsequently followed by relevant amendments and supplements to Criminal Code of the Republic of Serbia (hereinafter: the CC). ${ }^{7}$ Consequently, the criminal offence of violence at sports events, which was initially prescribed in the PVMSE Act, was now transferred to the Criminal Code and included in the section on "Criminal acts against Public Peace and Order" as a special criminal offence

\footnotetext{
${ }^{5}$ The Act on the Prevention of Violence and Misconduct at Sports Events, (Official Gazette of the Republic of Serbia, No. 67/03 from July 1, 2003, Official Gazette RS, No. 101/2005, Official Gazette RS, No. 90/2007, Official Gazette RS, No. 72/2009, Official Gazette RS, No. 111/2009, and Official Gazette RS, No. 104/2013) 6 National Youth Strategy, (Official Gazette of the Republic of Serbia, No. 55/2008) 7 Criminal Code of the Republic of Serbia (Official Gazette RS, No. 65/05 from 10 Oct. 2005, altered and amended: Official Gazette RS, No. 88/05, Official Gazette RS, No.107/05, Official Gazette RS, No. 72/2009, Official Gazette RS, No. 111/2009, Official Gazette RS, No. 121/2012, Official Gazette RS, No. 104/2013, Official Gazette RS, No. 108/2014, and Official Gazette RS, No. 94/2016)
} 
titled as "Violent Behaviour at Sport Events" (Article 344a CC) ${ }^{8}$. After this alteration, the provisions of the PVMSE Act continued to regulate only misdemeanour offences.

Since the date of its enforcement, 11 September 2009 up to date, this criminal offence (Article 344a CC) was amended only once, on 6 January 2010. Compared to the original text of the $\mathrm{CC}$, this amendment prescribes that it is mandatory to impose the security measure by which the court bans the perpetrators of the criminal offences from attending certain sports events and gatherings for a period of one to five years; this mandatory measure has been applied ever since, and it was amended only once in $2016 .{ }^{9}$ This security measure is imposed only on the perpetrators of criminal offences related to violence at sports events (Article 344a CC), whenever such prohibition is necessary for the protection of public safety. As prescribed, before the beginning of certain sports events, the perpetrator is obliged to personally report to the authorized official of a local police department in the area of his current residence or to the police station where he will be kept during the sports event.

In 2013, the Government of the Republic of Serbia adopted the National Strategy for Combating Indecent Behaviour at Sports Events (hereinafter: the National Strategy) ${ }^{10}$. It is a strategic document that determines the basic principles and policies of security and safety aimed at combating violence and misconduct at sports events. Besides the National Strategy, the Serbian Government also adopted the Action Plan for the Implementation of the National Strategy. The aforementioned documents constitute the basis for establishing an efficient mechanism for the prevention of indecent behaviour at sports events and gatherings, achieved by coordinated work of responsible state authorities. Their primary goal is to increase security at sports events and to devise security mechanisms for the prevention of violence, in accordance with the European standards. The Government specified that these changes have contributed to establishing an efficient mechanism which is to be applied in the process of charging the perpetrators of these criminal offences; another significant feature is that this mechanism provides for banning some high-risk groups or individuals from attending sports events.

The Government also formed the Action Team for the development and implementation of the Strategy and Action Plan for Combating Violence and Indecent Behaviour of Spectators at Sports Events. Moreover, in 2017, the Government issued the Decision on establishing the National Council for the prevention of negative phenomena in sports. ${ }^{11}$

All things considered, it may be concluded that the prevention of violence and indecent behaviour of spectators at sports events and gatherings includes numerous state authorities of the Republic of Serbia: the National Assembly, the Government of the Republic of Serbia, the Ministry of Internal Affairs, the Ministry of Youth and Sports, as well as the Public Prosecutor's Office, misdemeanour courts and sports associations (Milenković, Todorić, 2011: 25).

8 The Act on Amendments and Supplements to the Criminal Code RS (Official Gazette RS, No. 72/2009); the criminal offence of violence at sports events was regulated in Article 344a CC RS.

9 The Act on Amendments and Supplements to the Criminal Code (Official Gazette RS, No. 94/2016)

10 The National Strategy for Combating Indecent Behaviour at Sports Events for the period 2013-2018 (Official Gazette of the Republic of Serbia, No. 63/2013).

11 Decision on establishing the National Council for the prevention of negative phenomena in sports (Official Gazette RS, No. 79/2017). 


\section{OFFICIAL DATA ON SPORTS ViOLENCE}

The official data related to violence in sports and at sports events show a stable decrease in the number of criminal charges and convictions for the criminal offence of violent conduct at sports events or public gatherings (envisaged in Article 344a CC). This fact is confirmed both by the Serbian judiciary and by the police.

According to the data in the Bulletin of the Ministry of Internal Affairs of the Republic of Serbia published in April 2015, a total of 50,571 sports events were secured by the police forces in 2013 (in comparison to 47,081 events in 2012), 20\% of which occurred on the territory of the City of Belgrade Police Directorate. Moreover, despite a greater number of sports events in 2013 compared to that number in 2012, the statistics prove that these sports events were better secured in 2013 since the number of incidents decreased by one quarter, the number of injured persons was lower by $16 \%$, the number of damaged vehicles was reduced by $20 \%$, and the number of assaults on referees was reduced by $8 \%$. These data also show that there were fewer charges for the criminal offence of violent behaviour at sports events and gatherings, but that there were charges for other types of criminal offences at sports events, particularly the ones related to drug abuse. On the other hand, there was a dramatic increase in the offence of the violation of public peace and order, the offence envisaged in Article 23 of the Act on the Prevention of Violence and Misconduct at Sports Events (the PVMSE Act), but also a considerably smaller number of sanctioned offences envisaged in Article 21 of this Act. ${ }^{12}$

The latest Bulletin of the Ministry of Internal Affairs of the RS, published in April 2016, provides similar data, emphasizing that 61,781 public gatherings were successfully secured in 2015 (in comparison to 60,337 public gatherings in 2014), around $80 \%$ of which were sports events and gatherings (a total of 49,927 in 2015 and a total of 48,620 in 2014). ${ }^{13}$

The data obtained from the Ministry of Internal Affairs RS show a decrease in the number of criminal offences of violent behaviour at sports events or gatherings (Article 344a CC). These findings are confirmed by the latest official data published in 2016 by the Statistics Office of RS including statistics on reported, prosecuted and convicted cases involving adult criminal offenders.

Based on the data provided by the Ministry of Internal Affairs of the RS in 2016, a total of 3,201 adult individuals were reported for the commission of the criminal offence of violation of public order and peace, while only 108 perpetrators were reported for the criminal offence of violent behaviour at sports events (under Article 344a CC), which is approximately $3 \%$ of all reported criminal offences from this group of offences. Out of this number, a total of 39 individuals were reported for the commission of this criminal offence on the territory under the jurisdiction of the Appellate Court in Niš (covering the southern and eastern part of Serbia) or higher courts in this region, which comprises $35 \%$ of the total number of reported offenders for this criminal offence in the year 2016. In the same year, 2,274 individuals were charged with the offence of violation of public order and peace, but only 168 perpetrators were charged with the offence of violent behaviour at sports events (Article 344a CC). From the total number of 168 offenders charged with this offence, a total of 126 individuals were found guilty and sentenced in court. Except for one female

12 Bulletin of the Ministry of Internal Affairs of the Republic of Serbia, April 2015, p 87-88, available at: http://arhiva.mup.gov.rs/cms_lat/sadrzaj.nsf/arhiva-informator.h, accessed on 30 March 2018.

13 Bulletin of the Ministry of Internal Affairs of the Republic of Serbia, April 2016, p. 114, available at: http://arhiva.mup.gov.rs/cms_lat/sadrzaj.nsf/arhiva-informator.h, accessed on 30 March 2018. 
offender, all the other convicted offenders were male. As for the awarded sanctions, 20 offenders were imprisoned (most commonly for a period of up to 2 months, or 3-6 months, while only one offender was imprisoned for 2-3 years); fine was awarded in 12 cases (most commonly from 10,000 to100,000 RSD); suspended sentence was awarded in 18 cases; house arrest was imposed in 12 cases; ancillary penalty was awarded in 91 cases, and community service was awarded in only one case. In a total of 118 cases, the Serbian courts imposed the security measure banning the perpetrators from attending certain sports events. $^{14}$

\section{Disputable ISSUES IN JUdiCIAL PRACTICE}

Some disputable issues related to the criminal offence of violent behaviour at sports events or public gatherings (envisaged in Article 344a CC) may be illustrated by the description of the aspect of this criminal offence that has caused the greatest amount of controversy in judicial practice. The basic form of this criminal offence is defined in Article 344a CC, paragraph1, as follows: "Whoever physically assaults or engages in an affray with participants in a sporting event or public gathering; perpetrates violence or causes damage to property of substantial value while coming to or leaving a sporting event or a public gathering; brings into a sports facility or throws onto sports grounds, into a group of spectators or people attending a public gathering objects, fireworks, or other explosive, flammable or harmful substances which might cause bodily injuries or endanger the health of those partaking in the sporting event or public gathering; enters sports grounds or the section of the grandstand intended for supporters of the opposing team without authorization and precipitates violence, damages the sporting facility, its equipment, devices, and installations; behaves in such a way or shouts slogans or carry placards at a sporting event or public gathering as to provoke national, racial, religious, or some other type of hatred or intolerance based on some discriminatory reason which results in violence or a physical altercation with people partaking in the event or gathering, shall be punished with imprisonment of six months to five years and fined".

There is no dispute in judicial practice that the immediate participants in sports events (players, coaches and referees) are frequently affected by the commission of this criminal offence. However, the most frequently disputed issue is whether players, coaches and referees can be the perpetrators of this criminal offence in general, and particularly in case of their mutual confrontation at a sports event or gathering. As it has been a subject matter of a long-standing judicial argument, the Appellate Court in Niš as well as other appellate and higher courts in Serbia has changed their attitudes towards this dilemma. Namely, a number of judges used to defend the view that, in case of a physical confrontation among the participants on the playground and in the course of a sports event or gathering previously schedulled by the Sports Association of Serbia, the acts of violence and physical confrontation between the participants could not be treated as an act of commission of this criminal offence, nor could the participants be treated as the object of assault (Cvetković, 2011: 2).

\footnotetext{
${ }^{14}$ The Statistics Office of the RS, Bulletin 629: Adult Criminal Offenders in RS, 2016- Statistics on reported, prosecuted and convicted criminal cases, 2016; (pp. 13, 42, 64- 65, 72-73, 77); retrieved 26.03.2018 from http://www.stat.gov.rs/WebSite/repository/documents/00/02/72/06/SB-629-Punoletni_2016.pdf
} 
This standpoint was prominent in court practice on the territory under the jurisdiction of all appellate courts in Serbia until 2012. Thus, the Appellate Court in Niš observed this principle in individual decisions, considering that the criminal offence of violence at a sports event or gathering defined in Article 344a para.1 of the Criminal Code does not refer to the immediate participants in a sports event (players, coaches and referees) but to the spectators and fans ${ }^{15}$.

In 2012, acting upon the request of the Public Prosecutor's Office for the protection of legality, the Supreme Court of Cassation in Belgrade accepted the Prosecutor's complaint related to the judgment of the Appellate Court in Belgrade by which the defendants had been exonerated from all charges relating to the criminal offence of violent behaviour at a sports event or gathering, defined in Article 344a, para. 1 CC. The Supreme Court of Cassation proclaimed that the judgment of the Appellate Court in Belgrade, ruling in favour of the defendants, constituted a violation of Article 369 para. 1 of the Criminal Procedure Code (CPC) in conjunction with Article $344 \mathrm{a}$, para. 1 CC. ${ }^{16}$

In the justification of its ruling, the Supreme Court of Cassation stated the reasons for overturning the Appellate Court judgment: "The defendants D.N. and Z.V. were charged with and convicted of the criminal offence of violent behaviour at a sports event or public gathering, defined in Article 344a para. 1 of the CC. The judgment was rendered by the Trial Court for the defendants' involvement in the physical confrontation with each other in the course of the sports event as participants in that sports event, i.e. handball team coaches."

In its review of the contested Trial Court judgment, the Appellate Court in Belgrade explained its decision to overturn and modified the Trial Court judgment in this particular case and to exonerate the defendants of all criminal charges. The Appellate Court stated that the defendants, who were the participants in the sports event acting in the capacity of handball team coaches, could not be the perpetrators of the aforesaid criminal offence since the participants in sports events, who are regarded as obligatory and authorized participants in a sports event by the Sports Association Statute, could be neither passive nor active subjects in committing this criminal offence. The Appellate Court justified its review by referring to Article 1 of the European Convention on Spectator Violence and Misbehaviour at Sports Events and in particular at Football Matches, according the which the goal to be achieved by the Convention is the prevention and suppression of violence and indecent conduct of spectators at football matches and other sports events, as well as by referring to Article 1 of the Act on the Prevention of Violence and Misconduct at Sports Events in the Republic of Serbia, which states that this Act determines the measures for the prevention of violence and indecent behaviour at sports events, as well as the responsibility of organizers and authorized officials for their enforcement. Based on these documents, the Appellate Court concluded that, since the conduct of the participants in a sports event (players, coaches and referees) was regulated by the Sports Association Statute, it meant that in case of the demonstration of violence among the participants in the sports playground, they had to be sanctioned as prescribed by the Statute or other legal acts of the Association.

The Supreme Court of Cassation dismissed this order of the Appellate Court as wrong. Article $344 \mathrm{a}$ para. $1 \mathrm{CC}^{17}$ prescribes various alternative ways of committing this particular

\footnotetext{
15Judgment of the Appellate Court in Niš, Kž. No. 2037/11 of 10 January 2012 - unpublished

16 Judgment of the Supreme Court of Cassation, Kzz. No. 24/12 from 11 April 2012

${ }^{17}$ Article 344a para. 1 of the CC (Official Gazette of the Republic of Serbia, No. 111, of 12 December 2009)
} 
criminal offence, without putting any restrictions on the circle of potential perpetrators, provided that they are present at a sports event. The first of the prescribed alternative ways of committing this offence states that a perpetrator is the individual who physically assaults or uses violence to physically confront other participants in a sports event or public gathering, which is precisely the criminal offence for which the defendants N. and V. were found guilty as charged by the Trial Court. Article 2 para. 5 of the Act on the Prevention of Violence and Misconduct at Sports Events ${ }^{18}$ states that the participants in a sports event are all individuals present at that sports event. Therefore, a perpetrator of the criminal offence defined by Article 344a para. 1 CC and committed as determined by the Trial Court order (as a physical assault and physical confrontation) can be any individual who commits this offence against any other individual present at a sports event, or participating in it, regardless of their role in that sports event. Thus, the Supreme Court of Cassation held that the Appellate Court ruling, by which the players, coaches and referees were exonerated from charges as being neither passive nor active subjects in the criminal offence, was wrong because the provision in Article 344a, para.1 CC entails that that they were also considered participants present at the sports event.

As regards the legal documents of the Sports Association that the Appellate Court referred to in its judicial decision, Article 36 of the Sports Act ${ }^{19}$, which was effective at the time of commission of the criminal offence, as well as Article 102 of the Sports Act $(2011),{ }^{20}$ which came into force after the commission of this criminal offence, state that the branch sports associations shall adopt regulatory acts prescribing the sports rules to be respected in a particular sports branch. Among other things, these rules shall prescribe the measures for the prevention of negative phenomena in sports, as well as disciplinary proceedings and disciplinary sanctions for the violation of these prescribed rules. In particular, Article 35 of the Statute of the Serbian Handball Association prescribes that the members of the Handball Association of Serbia who act in contravention of the Statute and other general acts of the Handball Association of Serbia shall be subject to disciplinary measures and may be sanctioned in compliance with the rules prescribed in the Disciplinary Rules of the Handball Association of Serbia.

The European Convention on Spectator Violence and Misbehaviour at Sports Events and in particular at Football Matches, ${ }^{21}$ which the Appellate Court referred to in its ruling, is a legal framework that is binding on the Convention state parties and signatories, which are required to undertake relevant measures within the national legal framework to implement the Convention provisions; however, this treaty regulates only one segment of violence and misconduct at sports events - violence committed by spectators. As the Serbian Act on the Prevention of Violence and Misconduct at Sports Events ${ }^{22}$ defines the measures for the prevention of violence and misconduct of all persons attending a sports event, it implies that this Act regulates the behaviour of a wider circle of individuals, which is certainly not contrary to the provisions of the European Convention. Article 23 of this

\footnotetext{
${ }^{18}$ Article 2 para. 5 of the Act on the Prevention of Violence and Misconduct at Sports Events (Official Gazette $R S$, No. 67/2003, 101/2005, 90/2007, 72/2009 and 111/2009)

${ }^{19}$ Article 36 of the Sports Act (Official Gazette RS, No. 52/96 and 101/2005)

${ }^{20}$ Article 102 of the Sports Act (Official Gazette RS, No. 24/2011 и 99/2011)

${ }^{21}$ The European Convention on Spectator Violence and Misbehaviour at Sports Events and in particular at Football Matches (Official Gazette of the SFRY - international treaties, No. 9/90)

${ }^{22}$ Act on the Prevention of Violence and Misconduct at Sports Events (Official Gazette of the Republic of Serbia, No. 67/2003, 101/2005, 90/2007, 72/2009 и 111/2009)
} 
Act prescribes a misdemeanour liability of natural persons for misdemeanour offences committed at a sports event, but none of the prescribed misdemeanour offences includes the acts committed by the defendants D.N. and Z.V.; yet, physical assaults and physical confrontation among the individuals present at a sports event are prescribed (along with other alternative criminal acts) as a criminal offence in Article 334a para. 1 of the CC.

The application of the Criminal Code provisions in assessing who can be the perpetrator of the criminal offence defined in Article 344a para.1 of the CC and whether this criminal offence has been committed is not precluded by the fact that certain individuals present at a sports event have been previously sanctioned for disciplinary misdemeanour, defined by the relevant legal documents of the sports association.

Considering the aforesaid, it may be concluded that the provisions of the 1985 European Convention and the provisions of the Serbian Act on the Prevention of Violence and Misconduct at Sports Events do not preclude the application of Article 344a of the CC to all persons present at a sports event who commit any of the alternatively prescribed criminal acts envisaged in Article 344a para. 1 of the CC. For this reason, the Appellate Court ruling, which excluded all other persons present at the sports event (other than the spectators) from the circle of perpetrators of this offence, is unacceptable.

The judgment rendered by the Supreme Court of Cassation was highly significant for the national judicial practice because it clarified the disputable issue concerning whether the immediate participants in sports events (players, coaches and referees) could be the perpetrators of the criminal offence of violent behaviour at a sports event or public gathering, envisaged in Article 344a of the CC. For this reason, acting upon the appeal of the Higher Public Prosecution Office, the Appellate Court in Niš changed its stance by the judgment rendered in December 2012 and, referring to the cited judgment of the Supreme Court of Cassation (Kzz. No. 24/12), reversed and modified the Trial Court decision to exonerate the defendant, found the defendant guilty of violent behaviour, and imposed an appropriate sentence in accordance with the law ${ }^{23}$.

This appears to have been the most serious issue in court practice in the previous period, which was finally resolved by the cited judgment of the Supreme Court of Cassation in the judicial review procedure initiated by lodging a complaint for extraordinary legal remedy on a matter of law. Substantively, this judgment entailed the judicial interpretation of Article 344a para. 1 of the CC, which prescribes several alternative forms of commission of this criminal offence, without placing any restrictions on the circle of possible perpetrators of this criminal offence, provided that they are present at a sports event.

Concerning the perpetrators of this criminal offence, the judicial practice has encountered some other disputable issues, such as:

a) whether the club financier, who enters the sports field without authorization and assaults another participant in the sports event, is an authorized official of the club he finances and thus permitted to enter the field; the court practice indisputably established that the person is not an authorized club official because he attended the sports event as a spectator ${ }^{24}$;

b) whether the unregistered football players (not officially registered as team members for the game), who threaten and insult the referee, throw half-empty beer cans and hit the referee, and swing metal bars at the referee, are considered to be the football team

\footnotetext{
${ }^{23}$ Judgement rendered by the Appellate Court in Niš, Kž 1, No.1360/12 from 13 December 2012- unpublished

${ }^{24}$ Judgement rendered by the Appellate Court in Niš, Kž 1, No. 306/17 from 19 May 2017 - unpublished
} 
members/players even though they acted in the capacity of spectators, observing the football match from the stadium stands; in this case, the court practice indisputably established that they are not to be treated as players but as spectators ${ }^{25}$.

In the judicial practice of the Appellate Court in Niš, judges have encountered another disputable issues pertaining to Article $344 \mathrm{a}$ paragraph 4 of the $\mathrm{CC}$, which includes a qualified form of the criminal offence: "If the commission of the offence referred to in paragraph 1 of this Article has led to a public disorder, whereby a person has sustained a grievous bodily injury or substantial damage to property, the offender shall be punished by a term of imprisonment ranging from two to ten years" (Article 344a para. $4 \mathrm{CC}$ ). The point of argument here is whether there is a qualified form of this criminal offence if the consequence of the offence is absent, i.e. if the commission of the offence does not lead to causing public disorder but the defendant has caused a serious bodily injury to another person.

This issue was resolved in a judgment of the Appellate Court in Niš, which reasoned that: "For the qualified form of the criminal offence of violent behaviour at a sports event prescribed in Article 344a, para. 4 of the CC to exist, it is essential that the consequence of causing public disorder a sports event has occurred, for which reason another individual has sustained serious bodily injury; in case of the absence of consequence (i.e. if the defendant caused a serious bodily injury to another without causing a public disorder), such an act has all the legal elements of the criminal offence of grievous bodily injury prescribed in Article 121 paragraph 1 of the Criminal Code" ${ }^{\text {, }}$.

\section{CONCLUSION}

Violence in sports and in sports playgrounds has become a global phenomenon, which is present in all countries worldwide. This paper provides an overview and discusses the most significant international and national legal documents, which are important sources of law aimed at providing relevant legal protection of all participants in sports events. In particular, the paper focuses on examining and discussing the national legislative framework related to violence in sports in the Republic of Serbia. In Serbian legislation, this subject matter is regulated both by misdemeanour law and criminal law. Thus, in addition to numerous misdemeanour penalties, the legislator has envisaged a special criminal offence of violent behaviour at sport events, in Article 344a of the Criminal Code, which prescribes relevant sanctions for the criminal offence of violence in sports and/or sporting events.

The paper also indicates the most significant issues that have been observed in judicial practice regarding the criminal offence of violent behaviour at sports events (Article 344a $\mathrm{CC}$ ), the change of attitude in the judicial practice related to perpetrators of this criminal offence (in particular, concerning the issue whether players, coaches and referees are to be treated as potential perpetrators of this offence), as well as some landmark judicial decision regarding some debatable issues generally encountered in the Serbian judicial practice and particularly in the judicial practice the Appellate Court in Niš and higher (district) courts in

\footnotetext{
${ }^{25}$ Judgement rendered by the Appellate Court in Niš, Kž 1, No. 1888/11 of 13 October 2011 - unpublished

${ }^{26}$ Judgement rendered by the Appellate Court in Niš, Kž. 1, No. 1041/14 of 23 October, 2014, published in the Bulletin of the High Court in Niš, No. 33/2015, Intermex, Belgrade
} 
this region (as first-instance courts for adjudicating the criminal offence of violence in sports)..

This paper may be beneficial to foreign experts in the field who may be interested in examining the problems encountered in practice in terms of implementing the envisaged national legislative framework. On the other hand, it may be useful to Serbian law experts, legal practitioners and the judiciary in general who may be thus introduced to the current stance of the judicial practice towards this criminal offence.

\section{REFERENCES}

Cvetković, V. (2011). Objekt krivičnog dela - neka pitanja (The Object of Crime-some issues), Bilten sudske prakse Vrhovnog Kasacionog suda, Intermex, Beograd; http://www.sudskapraksa.com/Vrhovni\% 20kasacioni\%20sud\%20-\%20Bilten-1-2011.html

Dimovski, D., Ilić, I. (2015), Nasilje u sportu u Republici Srbiji-primer područja Višeg suda u Nišu (Sport Violence in the Republic of Serbia- in the territorial jurisdiction of the Higher Court in Niš), NBP Žurnal za kriminalistiku i pravo, Kriminalističko-policijska akademija, Beograd, available at http://www.kpa.edu.rs/ cms/data/akademija/nbp/NBP_2015_1.pdf (str.119-133); http://scindeks-clanci.ceon.rs/data/pdf/03548872/2015/0354-88721501119D.pdf, access 30.03.2018.

Jašarević, O., Samouk-Jašarević, M., (2016). Krivično pravni aspekti huliganstva kao fenomenološki oblik devijantnog ponašanja (Criminal Law Aspects of Hooliganism as a phenomenological form of deviant behaviour), (str. 643-655), Zbornik radova sa LVI Savetovanja Srpskog udruženja za krivičnopravnu teoriju i praksu, Intermex, Zlatibor

Milenković, D., Todorić, V. (2012). Pravni okvir sprečavanja nasilja i nedoličnog ponašanja na sportskim priredbama (Legal framework for preventing violence and misconduct at sports events), Centar za novu politiku, Beograd.

Stepanović, A., (2011). Nasilje na sportskim terenima-sa osvrtom na uporedno pravna rešenja (Violence at sports events, with an overview of comparative law solutions), Bilten Višeg suda u Beogradu, Intermex, Beograd.

\section{LEGAL ACTS}

Кривични законик (Criminal Code), "Сл. гласник $P C^{\prime \prime}$, бр.65/05 од 06.10.2005, са изменама и допунама:"Сл. гласник $P C^{\prime \prime}$, бр.88/05,"Сл. гласник $P C^{\prime \prime}$, бр.107/05, "Сл. гласник $P C^{\prime \prime}$, бр.72/2009,"Сл. гласник PC", бр.111/2009,"Сл. гласник PC", бр.121/2012, "Сл. гласник $P C^{\prime \prime}$, бр.104/2013, "Сл. гласник $P C^{\prime \prime}$, бр.108/2014, "Сл. гласник $Р C^{\prime \prime}$, бр.94/2016.

Закон о изменама и допунама Кривичног законика (Act on Amendments and Supplements to the Criminal Code RS), "Сл. гласник PC", бр. 72/2009- кривично дело из чл.344а КЗ.

Закон о изменама и допунама Кривичног законика (Act on Amendments and Supplements to the Criminal Code RS)", Сл. гласник PC", бр. 111/2009.

Закон о изменама и допунама Кривичног законика (Act on Amendments and Supplements to the Criminal Code RS). "Сл. гласник РC", бр. 94/2016.

Закон о спречавању насиља и недоличног понашања на спортским приредбама, (Act on the Prevention of Violence and Misconduct at Sports Events, the PVMSE Act), "Сл. гласник РС", бр. 67/03 од 01.07.2003. године, са изменама и допунама и то:"Сл. гласник РС", бр. 101/2005, "Сл. гласник РС", бр. 90/2007, "Сл. гласник РС", бр. 72/2009, "Сл. гласник РС", бр. 111/2009,"Сл. гласник РС", бр. 104/2013).

Национална стратегија за младе (The National Youth Strategy),"Сл. гласник $P C^{\prime \prime}$, бр. 55/2008

Национална стратегија за борбу против недоличног понашања на спортским приредбама за период од 2013. до2018.године (National Strategy for Combating Indecent Behaviour at Sports Events for the period 2013-2018), "Сл. гласник PC", бр. 63/2013.

Одлука о образовању Националног савета за спречавање негативних појава у спорту (Decision on establishing the National Council for the Prevention of Negative Phenomena in Sports), "Сл. гласник PC", бр. 79/2017. 


\section{INTERNET RESOURCES}

Министарство унутрашњих послова Републике Србије, Информатор о раду Министарства унутрашњих послова Републике Србије, април 2015. (Bulletin of the Ministry of Internal Affairs of the Republic of Serbia, April 2015), стр.87-88, http://arhiva.mup.gov.rs/cms_lat/sadrzaj.nsf/arhiva-informator.h, accessed 30 March 2018.

Министарство унутрашњих послова Републике Србије, Информатор о раду Министарства унутрашњих послова Републике Србије, април 2016. (Bulletin of the Ministry of Internal Affairs of the RS, April 2016), стр.114, http://arhiva.mup.gov.rs/cms_lat/sadrzaj.nsf/arhiva-informator.h, accessed 30. March 2018.

Републички завод за статистику, Република Србија, Билтен 629: Пунолетни учиниоци кривичних дела у Републици Србији, 2016,-Пријаве, оптужења и осуде, Републички завод за статистику (Bulletin 629: Adult Criminal Offenders in RS, 2016-Statistics on reported, prosecuted and convicted criminal cases, The National Statistics Office of the RS), available at: http://www.stat.gov.rs/WebSite/repository/documents/ 00/02/72/06/SB-629-Punoletni_2016.pdf, accessed 26 March 2018.

Vreme, Slučaj "Maksimir" - dvadeset godina posle, by Z.Majdin, br. 1011, 20 maj 2010; available at http://www.vreme.co.rs/cms/view.php?id=931952, accessed 20 March 2018.

The Guardian, Greek Superleague suspended after team owner invades pitch with a gun, by H.Smith, 12 March 2018; available at https://www.theguardian.com/football/2018/mar/12/greek-football-match-stopped-afterteam-owner-invades-pitch-with-a-gun, accessed on 20 March 2018.

The Guardian, West Ham promise to ban fans for life after Upton Park violence, by A. Smith, D. Hytner, 11 May 2016, available at https://www.theguardian.com/football/2016/may/11/west-ham-ban-fans-for-lifeupton-park-violence-manchester-united, accessed on 20 March 2018.

\section{CASE LAW}

Пресуда Апелационог суда у Нишу (Judgment of the Appellate Court in Niš), Кж.1.бр.1888/11 од 13.10.2011.године - необјављена

Пресуда Апелационог суда у Нишу (Judgment of the Appellate Court in Niš), Кж.1.бр.2037/11 од 10.1.2012.године - необјављена

Пресуда Врховног касационог суда (Judgment of the Supreme Court of Cassation), Кзз 24/12 од 11.04.2012. године

Пресуда Апелационог суда у Нишу (Judgment of the Appellate Court in Niš), Кж.1.бр.1360/12 од 13.12.2012.године - необјављена

Пресуда Апелационог суда у Нишу (Judgment of the Appellate Court in Niš), Кж.1.бр.1041/14 од 23.10.2014.године - објављена у Билтену Вишег суда у Нишу, број 33/2015, Интермех, Београд

Пресуда Апелационог суда у Нишу (Judgment of the Appellate Court in Niš), Кж.1.бр.306/17 од 19.5.2017.године - необјављена

\section{ZAKONSKA REGULATIVA NASILJA U SPORTU I SPORNA PITANJA KROZ ANALIZU SUDSKE PRAKSE}

Zakon o sprečavanju nasilja i nedoličnog ponašanja na sportskim priredbama, reguliše ponašanje učesnika sportskih priredbi i sadrži brojne novine u vezi sa ovim oblikom kriminalne delatnosti. Na velikim sportskim događajima neretko dolazi do ozbiljnog ispoljavanja nasilja, uništavanja imovine $i$ nanošenja telesnih povreda, nekada i smrtnog ishoda, kao posledica nasilja na koje su nadležni državni organi obavezni da reaguju. U ovom radu predstavićemo najvažnije odredbe koje se odnose na važeću zakonsku regulativu koja reguliše ovaj oblik nasilja uz analizu određenih spornih pitanja $i$ deo dosadašnje sudske prakse. Posebno, ukazaćemo na određene probleme u praksi sudova.

Ključne reči: sport, nasilje, zakonska regulativa, problemi u praksi 